International Journal of Health Sciences
Available online at www.sciencescholar.us
Vol. 6 No. 1, April 2022, pages: 160-173
e-ISSN: 2550-696X, p-ISSN: 2550-6978
https://doi.org/10.53730/ijhs.v6n1.3626

\title{
Adverse Events Following Immunization Post Moderna (mRNA- 1273) Booster Vaccination After Two Primary Doses of CoronaVac
}

Irzal Rakhmadhani a, Erna Yulida b, Akhmad Fauzan c, Abdul Kadir Jaelani d
Manuscript submitted: 4 September 2021, Manuscript revised: 9 December 2021, Accepted for publication: 5 January 2022

International Journal of Health Sciences (C) 2022. This is an open access article under the CC BY-NC-ND license (https://creativecommons.org/licenses/by-nc-nd/4.0/).

\footnotetext{
Contents

Abstract

1 Introduction

2 Materials and Methods

3 Results and Discussions

a District Health Office of Hulu Sungai Utara, South Kalimantan, Indonesia

b District Health Office of Hulu Sungai Utara, South Kalimantan, Indonesia

c District Health Office of Hulu Sungai Utara, South Kalimantan, Indonesia

d Universitas Sebelas Maret, Surakarta, Indonesia
} 


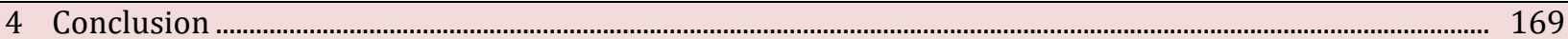

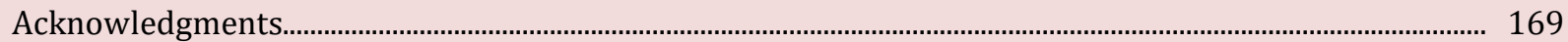

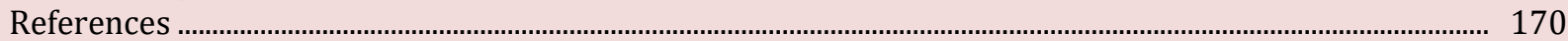

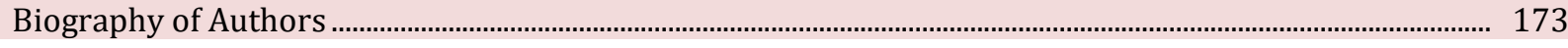

\section{Introduction}

The COVID-19 pandemic places a great deal of strain on health care employees' physical and mental wellbeing. Due to their high virus exposure in the workplace, health care professionals are the population most at risk during the COVID-19 pandemic. The World Health Organization (WHO) reports that health workers and administrators have the highest morbidity and fatality rates, with $14 \%$ of health workers worldwide infected with COVID-19 (Suryasa et al., 2021). This number increased to 35\% in low- and middle-income countries. Along with physical risks, the COVID-19 pandemic has increased the risk of mental health problems in health professionals, such as somatization, obsessive-compulsive disorder, anxiety, and phobias (Martyniv et al., 2021).

The high mortality rate of health workers in the second wave of the COVID-19 pandemic has become a severe problem in Indonesia (Tetro, 2020). As of September 17, 2021, there have been 2,029 deaths from various health professions. The mortality rate of health workers in Indonesia got the highest rank in Asia and the third rank globally. The death of these health workers causes various problems, including obstacles in handling the COVID-19 pandemic in health facilities; Increased workload of other health workers and burnout; Increased anxiety to be infected or infecting the family; and reduced quality of health services during the pandemic (Shamshurinaet al., 2021).

The ratio of medical personnel death compared to the total confirmed deaths of COVID-19 in Indonesia is one of the highest globally (2.1\%). This incident is due to the lack of PPE for health service providers, the lack of an adequate COVID-19 exposure screening for patients in health facilities, burnout of medical personnel due to the increased number of COVID-19 patients, long working hours, and psychological pressure (Lytvyn et al., 2021). Deteriorating physical and mental conditions as a result of this incident was eventually cause health workers exposed to COVID-19 with a higher risk of death. One of the solutions in reducing the morbidity and mortality number of Indonesian health workers was to prioritize the COVID-19 vaccination for Indonesian health workers (two doses) since February 2021. The COVID-19 vaccination for health workers was carried out in phase 1, with implementation from January to April 2021 (Suiraokaet al., 2021). This phase used a platform inactivated virus vaccine of the CoronaVac type produced by Sinovac Research and Development Co., Ltd. This vaccine was given in two doses, $0.5 \mathrm{ml}$ each, with an interval of 14 days. The vaccine was injected intramuscularly in the left arm after the people were screened, including checking body temperature, blood pressure and interviewing the risk of exposure to COVID-19 and contraindications to vaccination by experienced vaccinators (Mariya et al., 2021).

The CoronaVac vaccination has been quantitatively proven to reduce the mortality rate of health workers in Indonesia. In January 2021 there were 165 health workers died, which decreased to 82 deaths in February 2021 and 24 deaths in May 2021. The transmission of more infectious and virulent VOC, especially the deltas variant in the second wave of the COVID-19 pandemic, caused a significant increase in the death rate for Indonesian health workers in July 2021, which reached 492 people (Kim \& Su, 2020). High viral load, comorbidities, viral mutations in the Variant of Concern (VOC), and neglect of health protocols are essential factors that cause an increment of infection and mortality even though the person has been vaccinated (Candra et al., 2021).

The increase in illnesses and severe symptoms among Indonesian health professionals raises worries about the efficiency of CoronaVac, which is used to treat VOCs. Numerous research indicates that CoronaVac's durability degrades over time. According to a survey conducted by Patamatamkul et al. (2021), only 12.5\% of respondents developed antibodies over the cut-off threshold three months following the complete dose. Other types of vaccines exhibit a similar issue (Nataliia et al., 2021) According to Israeli researchers, the risk of infection was much higher among those who had previously received the Pfizer/BioNTech (BNT162b2) vaccination during the pandemic than among those who received the vaccine later. This dramatic spike in health worker mortality prompted the Indonesian government to release a third dose vaccination (booster) Rakhmadhani, I., Yulida, E., Fauzan, A., \& Jaelani, A. K. (2022). Adverse events following immunization Post Moderna (mRNA-1273) booster vaccination after two primary doses of CoronaVac. International Journal of Health Sciences, 6(1), 160-173. https://doi.org/10.53730/ijhs.v6n1.3626 
utilizing a different vaccine platform (mRNA-based). Moderna (mRNA-1273) was chosen as the vaccine and will begin in August 2021. The National Immunization Expert Advisory Committee, or ITAGI, recommended the third dose of immunization for health personnel based on a study done and presented to the Ministry of Health via letter number 71/ITAGI/Adm/VII/2021 dated July 8, 2021. On July 23, 2021, the Director-General of P2P issued a circular letter HK.02.01/I/1919/2021 requiring all health workers, assistant health workers, and support workers who work in health service facilities to receive the third dose of vaccination (Sukismanto et al., 2021; Akbarov \& Xabilov, 2021).

The third dose of vaccination was administered intramuscularly at a dose of $0.5 \mathrm{ml}$ using the Moderna (mRNA-1273) vaccine. The screening procedure, service flow, and observation procedures used to administer the third dose of vaccination with the Moderna (mRNA-1273) vaccine were identical to those used with the Sinovac and Astra Zeneca vaccines (Urinov et al., 2021). Booster vaccinations with various types of vaccines than the initial dosage are referred to as a mix and match strategy or heterologous vaccines (Kaml et al., 2006; Zepp et al., 2011; Schwarz et al., 2009). This method is implemented by administering the same antigen via two distinct types of vaccinations. The initial dose establishes the immune system, while future doses delivered by another platform may amplify the immunological response. Numerous studies have been undertaken to test the efficacy of heterologous vaccines utilizing a combination of chimpanzee adenovirusvectored vaccines (ChAdOx1 nCoV-19) or AstraZeneca's mRNA-1273 vaccine and Pfizer/BNT162b2 BioNTech's vaccine. The technique of mixing and matching vaccines is likely to boost protection against SARSCoV2 exposure and have a more significant and long-lasting effect than a single vaccine (Rahkmonova et al., 2021).

Additional research is needed to establish the efficacy of the booster immunization following two doses of CoronaVac, which is primarily administered in Indonesia. jmy research underlines the importance of a booster dosage following CoronaVac, particularly for at-risk populations such as health care workers, persons with chronic conditions, and the elderly (Vokhidov et al., 2021), Boosters are intended to sustain herd immunity until the results of other research utilizing different types of vaccinations are available. Boosters are administered to senior people above the age of 60 based on research indicating that the elderly have lower antibody titers. Meanwhile, studies on health professionals in Chile found that 5 months after receiving the second dosage of CoronaVac, antibody titers decreased (Iurii et al., 2021), Booster doses of mRNA-1273 vaccines given six to eight months following a total CoronaVac treatment have been shown to boost and stabilize antibody titers. This research demonstrates the booster's efficacy, particularly in dealing with the delta variation. Follow-up research can aid in determining the boosters' long-term efficacy against known variations (Manullang, 2021; Widana et al., 2021).

The Moderna Interim Analysis stated that the third dose of the mRNA-1273 vaccine would increase the antibody titer against the new variant. Another study found that the incidence of confirmed COVID-19 and severe symptoms decreased significantly in elderly respondents who received a booster (third dose) of BNT162b2 after five months of the second dose. The US Food and Drug Administration (FDA) has authorized the emergency use of the third dose of Pfizer and Moderna COVID-19 vaccines for certain immunocompromised people, including organ transplant recipients. However, the safety and effectiveness review of booster doses in other members of the adult population is still investigating by FDA. At the same time, the Centers for Disease Control and Prevention (CDC) is conducting an evidence-based review of booster administration (Zulfa et al., 2021; Wahyuni et al., 2022).

Then, in October 2021, the United States mandated the use of a COVID-19 immunization booster for the eligible population (Heininger, 2004; Erickson et al., 2005; Cuenca et al., 1996). Emergency Use Authorizations have been given for the use of a single dosage booster of mRNA-1273 vaccination at least six months after the completion of the initial dose in individuals aged 65 years and younger who are at risk of exposure to COVID19 , such as health care professionals and public assistants. This decision was made based on an FDA study demonstrating a favorable response to the respondent's antibody titer following 29 days of booster dosing (Arungpadang et al., 2021). The third dosage (booster) of COVID-19 vaccinations has not been studied in the general population. There has been an increase in adverse events (AEFI) such as fever, headache, joint pain, and malaise, particularly among the elderly. However, an increase in AEFI is uncommon and is associated with a favorable hematological and biochemical profile, as well as rapid clinical recovery. It has been hypothesized that the younger population may experience a bigger increase in adverse events as a result of increased systemic reactogenicity (Bocheliuk et al., 2021). 
Health workers are at the forefront of handling COVID-19 patients and have a high risk of contracting COVID-19. Six months after the health workers' vaccination, it was observed that antibodies started to decrease (Asman et al., 2021) Thus, health workers need to be given a COVID-19 booster vaccine, especially to deal with new variants. There is still limited study on AEFI that occurs in the delivery of booster doses of COVID-19 vaccination worldwide, especially in Indonesia. Therefore, the researcher is interested in knowing the Adverse Events Following Immunization (AEFI) after the Third Dose of COVID-19 Vaccination in Health Workers in Hulu Sungai Utara Regency.

\section{Materials and Methods}

This is descriptive research with the cross-sectional method. The research subjects were health workers who received the third vaccination dose in the Hulu Sungai Utara district. The respondents were health workers from the public health center, hospitals/clinics, and the Health Services who were willing to be research subjects (Wijaya \& Ali, 2021). This research was conducted virtually via google-form in their respective work areas. The survey took about 10 minutes, using Bahasa (Lintang et al., 2020). The study was born on August 10 - September 4, 2021. Data was collected by using purposive sampling. Health workers who were respondents in this study were asked to fill in the following data:

- Willingness (informed consent) to be a research respondent;

- Identity of the respondent (name, age, gender);

- Service categories (direct, indirect, and health administration services);

- Origin of health facilities;

- History of previous illness and previous history of COVID-19 infection;

- Medicines that are currently consumed;

- History of AEFI in previous CoronaVac vaccination (type of complaint, onset, treatment);

- Types of AEFIs in the administration of the mRNA-1273 booster were Local AEFIs (pain, swelling, and redness) and Systemic AEFIs (fatigue, headache, muscle aches, joint pain, chills, nausea and vomiting, fever, cough, and runny nose)

- Degree of current AEFI (mild, moderate, severe, death)

- Onset (time of occurrence) of the current AEFI;

- Duration of AEFIs;

- Activity after obtaining mRNA-1273 booster (whether the respondent was still working)

- Did they need hospitalization when the AEFI occurred.

Data was collected, stored, and analyzed in Microsoft office Excel version 2019.

\section{Results and Discussions}

A total of 261 respondents filled out the questionnaire, 1 respondent refused to fill in the data, and 2 respondents filled in the data twice. A total of 258 respondents were included as research subjects. The age of the respondents was between $18-58$ years with a median of 34 years. Most of the respondents were women $(72.87 \%, \mathrm{n}=188)$ and included in the group of direct service providers $(77.91 \%, \mathrm{n}=201)$. The direct service providers in this study are health workers who have direct contact with suspected, close contacts, or confirmed COVID-19 patients. (Karjoko, Handayani, et al., 2021) Most of the respondents had no previous history of AEFI (61.63\%, $n=159)$ and had never been infected with COVID-19 (94.19\%, $n=243)$. The general characteristics of the respondents are shown in Table 1.

Rakhmadhani, I., Yulida, E., Fauzan, A., \& Jaelani, A. K. (2022). Adverse events following immunization Post Moderna (mRNA-1273) booster vaccination after two primary doses of CoronaVac. International Journal of Health Sciences, 6(1), 160-173. https://doi.org/10.53730/ijhs.v6n1.3626 
Table 1

Baseline characteristic

\begin{tabular}{lrrr}
\hline & $\begin{array}{c}\text { All Recipients } \\
(\mathrm{n}=258)\end{array}$ & \multicolumn{1}{c}{$\begin{array}{c}\text { Local AEFIs } \\
(\mathrm{n}=257)\end{array}$} & \multicolumn{1}{c}{$\begin{array}{c}\text { Systemic AEFIs } \\
(\mathrm{n}=239)\end{array}$} \\
\hline Age, median (IQR), years & $34(30-41)$ & $34(30-41)$ & $34(29-41)$ \\
Sex, n (\%) & & & \\
$\quad$ Male & $70(27,13)$ & $70(27,24)$ & $67(28,03)$ \\
$\quad$ Female & $188(72,87)$ & $187(72,76)$ & $172(71,97)$ \\
Occupation, n (\%) & & \\
$\quad$ Direct Healthcare Workers & $201(77,91)$ & $200(77,82)$ & $183(76,57)$ \\
$\quad$ Undirect Healthcare Workers & $44(17,05)$ & $44(17,12)$ & $43(17,99)$ \\
$\quad$ Administrative Staff & $13(5,04)$ & $13(5,06)$ & $13(5,44)$ \\
History of AEFIs, n (\%) & & & \\
$\quad$ Yes & $99(38,37)$ & $99(38,52)$ & $94(39,33)$ \\
$\quad$ No & $159(61,63)$ & $158(61,48)$ & $145(60,67)$ \\
History of confirmed SARS CoV-2 infections & & & \\
$\quad$ Yes & $15(5,81)$ & $15(5,84)$ & $15(6,28)$ \\
$\quad$ No & $243(94,19)$ & $242(94,16)$ & $224(93,72)$ \\
\hline
\end{tabular}

Most of the respondents had no previous medical history $(62.79 \%, \mathrm{n}=162)$ with the three most common diseases, such as: dyspepsia $(15.89 \%, \mathrm{n}=41)$, bronchial asthma $(6.98 \%, \mathrm{n}=18)$, and COVID-19 infection $(5.81 \%, n=15)$. Respondents with a history of severe illness were not targeted for booster vaccination because they had not received a complete primary dose before (Mishra \& Negi, 2021). The majority of respondents had no previous routine medication $(86.43 \%, \mathrm{n}=223)$. The routine medications recorded were NSAIDs (4.26\%), Calcium Channel Blockers (3.1\%), and Robotansia (1.55\%). Past medical history and medical history of respondents are shown in Table 2 and Table 3.

Table 2

History of previous illnesses

\begin{tabular}{lcc}
\hline Type of Illnesses & $\mathrm{n}$ & $\%$ \\
\hline Dyspepsia & 41 & 15,89 \\
Asthma & 18 & 6,98 \\
History of Confirmed SARS CoV-2 infections & 15 & 5,81 \\
Hypertension & 12 & 4,65 \\
Hyperthyroidism & 5 & 1,94 \\
AV Blockade & 1 & 0,39 \\
Gallbladder Stone & 1 & 0,39 \\
Diabetes Mellitus & 1 & 0,39 \\
Low Back Pain & 1 & 0,39 \\
Tuberculosis & 1 & 0,39 \\
None & 162 & 62,79 \\
Total & 258 & 100 \\
\hline
\end{tabular}

Table 3

History of medication

\begin{tabular}{lrr}
\hline Type of Medication & $\mathrm{n}$ & $\%$ \\
\hline NSAID & 11 & 4,26 \\
Calcium Channel blocker & 8 & 3,10 \\
Roboransia & 4 & 1,55 \\
\hline
\end{tabular}




\begin{tabular}{lrr}
\hline Antasida / Sukralfat / Antagonis Resptor H2 & 3 & 1,16 \\
Beta Blocker & 2 & 0,78 \\
Bronchodilators & 2 & 0,78 \\
Antihistamines & 1 & 0,39 \\
Biguanide & 1 & 0,39 \\
ACE inhibitor & 1 & 0,39 \\
Xanthine oxidase inhibitor & 1 & 0,39 \\
Anti-Tuberculosis Drugs & 1 & 0,39 \\
None & 223 & 86,43 \\
Total & 258 & 100 \\
\hline
\end{tabular}

There were only $38.37 \%$ of respondents $(n=99)$ experienced AEFIs at the two primary doses of CoronaVac. The main AEFI were malaise (36.36\%), pain at the injection site $(32.32 \%)$, and fever $(22.22 \%)$ with the majority of onset occurring in 1-5 days (24.81\%). Most of the respondents did not require medication to reduce complaints (72.48\%) while the rest used NSAIDs (Yussoff \& Nordin, 2021), Characteristics of AEFI and medical history at the primary dose of Coronavac can be seen in Table 4.

Table 4

Type of AEFIs and History of Medication on Previous AEFIs

\begin{tabular}{|c|c|c|}
\hline & $\mathrm{n}$ & $\%$ \\
\hline \multicolumn{3}{|c|}{ History of AEFIs After Two Doses of Coronavac $(n=258)$} \\
\hline Yes & 99 & 38,37 \\
\hline No & 159 & 61,63 \\
\hline \multicolumn{3}{|c|}{$\begin{array}{l}\text { Symptoms of AEFIs After Two Doses of Coronavac } \\
(n=99)\end{array}$} \\
\hline Malaise & 36 & 36,36 \\
\hline Local Pain & 32 & 32,32 \\
\hline Fever & 22 & 22,22 \\
\hline Headache & 16 & 16,16 \\
\hline Increased Appetite & 11 & 11,11 \\
\hline Myalgia, arthralgia & 10 & 10,10 \\
\hline Nausea & 7 & 7,07 \\
\hline Rhinorea & 4 & 4,04 \\
\hline Rash & 3 & 3,03 \\
\hline Angina & 2 & 2,02 \\
\hline \multicolumn{3}{|c|}{$\begin{array}{l}\text { The onset of AEFIs After Two Doses of Coronavac } \\
(n=99)\end{array}$} \\
\hline$<30$ minutes & 31 & 31,3 \\
\hline 1-5 days & 64 & 64,6 \\
\hline 6-10 days & 1 & 1 \\
\hline$>10$ days & 3 & 3 \\
\hline \multicolumn{3}{|c|}{ Medication After Two Doses of Coronavac $(n=258)$} \\
\hline None & 187 & 72,48 \\
\hline NSAID & 62 & 24,03 \\
\hline H2 Receptor Antagonist & 4 & 1,55 \\
\hline Antacid & 3 & 1,163 \\
\hline PPI & 2 & 0,775 \\
\hline Antihistamines & 2 & 0,775 \\
\hline Roboransia & 4 & 1,55 \\
\hline
\end{tabular}

Rakhmadhani, I., Yulida, E., Fauzan, A., \& Jaelani, A. K. (2022). Adverse events following immunization Post Moderna (mRNA-1273) booster vaccination after two primary doses of CoronaVac. International Journal of Health Sciences, 6(1), 160-173. https://doi.org/10.53730/ijhs.v6n1.3626 
The incidence of AEFI that occurs after a single booster dose of the mRNA-1273 vaccine was very high. From all respondents, it was found that $99.61 \%(\mathrm{n}=257)$ experienced local AEFIs. Local AEFI complaints included pain at the injection site (95.35\%), swelling (37.6\%), and a red rash (11.24\%). While systemic AEFI occurred in $92.64 \%$ of respondents $(\mathrm{n}=239)$ with the most complaints in the form of myalgia $(70.93 \%)$, fever $(62.02 \%)$, and malaise (38.37\%). Most of the respondents experienced more than 1 symptom of local and systemic AEFI and admittedly it was quite disturbing their daily activities. The onset of AEFI occurred in the period 1-5 days after injection (74.32\%) (Noor et al., 2021). This group admitted that they only felt complaints 24 hours after giving the booster, starting with local AEFIs then followed by systemic AEFIs 2-5 days later. Most of the respondents (56.6\%) felt complaints about 24-48 hours which improved with the administration of NSAIDs (75.58\%). Most of the respondents (68.22\%) continued to work after the booster vaccination. None of the respondents required hospitalization (serious AEFI). (Putri et al., 2021) No deaths were reported in this study. Data on AEFI booster mRNA-1273 and post-booster responder activity are presented in Table 5 and Table 6.

Table 5

Incidence, symptoms, onset, and medication of AEFIs after mRNA-1273 booster

\begin{tabular}{|c|c|c|}
\hline & $\mathrm{n}$ & $\%$ \\
\hline \multicolumn{3}{|l|}{ Local AEFIs (n=258) } \\
\hline None & 1 & 0,39 \\
\hline Pain & 246 & 95,35 \\
\hline Swelling & 97 & 37,60 \\
\hline Rashes & 29 & 11,24 \\
\hline \multicolumn{3}{|l|}{ Systemic AEFIs ( $\mathrm{n}=258$ ) } \\
\hline None & 19 & 7,36 \\
\hline Myalgia & 183 & 70,93 \\
\hline Fever & 160 & 62,02 \\
\hline Malaise & 99 & 38,37 \\
\hline Chills & 91 & 35,27 \\
\hline Arthralgia & 91 & 35,27 \\
\hline Nausea & 32 & 12,40 \\
\hline Rhinorea & 15 & 5,81 \\
\hline Insomnia & 3 & 1,16 \\
\hline Anxiety & 1 & 0,39 \\
\hline Diarrhea & 1 & 0,39 \\
\hline \multicolumn{3}{|l|}{ Onset of AEFIs $(n=257)$} \\
\hline$<30$ minutes & 26 & 10,12 \\
\hline$<24$ hours & 40 & 15,56 \\
\hline 1-5 days & 191 & 74,32 \\
\hline \multicolumn{3}{|l|}{ Duration $(n=257)$} \\
\hline$<24$ hours & 85 & 33,07 \\
\hline 24-48 hours & 146 & 56,81 \\
\hline$>48$ hours & 26 & 10,12 \\
\hline \multicolumn{3}{|l|}{ Medication (n=257) } \\
\hline None & 53 & 20,62 \\
\hline NSAID & 195 & 75.88 \\
\hline Roboransia & 16 & 6.23 \\
\hline Antihistamines & 7 & 2.72 \\
\hline PPI & 2 & 0.78 \\
\hline H2 Antagonist Receptor & 1 & 0.39 \\
\hline Antacid & 1 & 0.39 \\
\hline
\end{tabular}


Table 6

Recipients activities After mRNA-1273 booster

\begin{tabular}{lcc}
\hline & $\mathrm{n}$ & $\%$ \\
\hline Working Activities After Booster & & \\
$\quad$ No & 82 & 31,78 \\
$\quad$ Yes & 176 & 68,22 \\
Hospitalization & & \\
$\quad$ No & 258 & 100 \\
Yes & 0 & 0 \\
\hline
\end{tabular}

COVID-19 infected and spread among health workers is a serious concern by various parties. The second wave of COVID-19 in Indonesia which is due to the delta variant has a huge impact. This virus was widespread in almost all provinces, resulting in an extremely high risk of transmission to health workers. The significant increase in COVID-19 infections and deaths in health workers who have received two complete doses of vaccination is a consideration for the Indonesian government in carrying out the third dose (booster) vaccination. This is a follow-up to the recommendation to give a booster with a single dose of mRNA-1273 from the National Immunization Expert Advisory Committee or ITAGI based on the results of a study conducted and submitted to the Ministry of Health through letter number 71/ITAGI/Adm/VII/2021 dated July 8, 2021 (Prasetyo et al., 2019).

The third dose of vaccination for health workers in Indonesia has been carried out since the end of July 2021. The third dose of vaccination uses the Moderna (mRNA-1273) vaccine with a dose of $0.5 \mathrm{ml}$ intramuscularly in the left arm (Kong et al., 2021). This vaccination is mandatory for all health workers who had been vaccinated doses 1 and 2 within the last 3 months. In the journey, there have been many Adverse Events Following Immunization (AEFI) in administering the third dose of vaccination to health workers in Indonesia Many people still question the effectiveness, efficacy, and safety of booster doses by using different types of vaccines (Kajoko et al., 2019) Existing research shows that after using the mRNA booster vaccine, the antibodies increased significantly and the protection against COVID-19 infection also increased, although there were no specific study results for inactivated vaccines followed by mRNA booster vaccines (Handayani et al., 2019).

The immune response to vaccination is different for each individual and antibody levels will decrease over time. A booster vaccination is currently an option and is still being closely investigated. In various countries in the world, boosters are carried out for patients who have high risks such as immunocompromised patients and hemodialysis patients. Turkey started booster vaccinations in July for health workers and the public over the age of 50. This country used CoronaVac and Pfizer/ BioNTech (BNT162b2) vaccines by encouraging people who have received a full dose of CoronaVac to use Pfizer/ BioNTech (BNT162b2) vaccine as a booster when traveling to other countries that have not recognized the CoronaVac vaccine. Similar steps were followed by Uruguay, Cambodia, and Thailand. The United States started booster injections for most adults on September 20, 2021, with a recommendation that a third dose is given eight months after the second dose. Health workers, nursing home residents, and the elderly who got the vaccine early were prioritized for boosters (Jaelani et al., 2020).

In clinical phase 1 and 2 research, it was found that giving a homologous and heterologous booster dose (mix and match) to respondents who received a complete dose of vaccine-type Pfizer/ BioNTech (BNT162b2), Moderna (mRNA-1273), or Janssen followed by a booster vaccine resulted in the anamnestic immune response. The antibody titer after the heterologous booster was similar or higher than the homologous booster dose (McMahon et al., 2021). The study from Mofaz et al reported that systemic AEFI reactions at the third dose (booster) of BNT162b2 mRNA were similar to AEFI reactions at the second dose but occurred more frequently than the first dose [23]. In clinical trials of booster doses of mRNA and Janssen, the incidence of local or systemic AEFIs was similar or lower at booster doses than in previous doses of AEFIs. No serious AEFIs have been reported with booster mRNA vaccines. Besides clinical trials, more than 13 million people in the United States had received additional or booster doses of the COVID-19 vaccine as of October 25, 2021,

Rakhmadhani, I., Yulida, E., Fauzan, A., \& Jaelani, A. K. (2022). Adverse events following immunization Post Moderna (mRNA-1273) booster vaccination after two primary doses of CoronaVac. International Journal of Health Sciences, 6(1), 160-173. https://doi.org/10.53730/ijhs.v6n1.3626 
mainly with Pfizer/ BioNTech (BNT162b2). No unexpected side effects occurred during observation by the national security surveillance system (Sudarwanto et al., 2021).

258 health workers took the mRNA-1273 booster vaccination willing to participate in this study. At the time this research was conducted, only health workers were required to receive a booster vaccination in Indonesia. Health workers following the third dose of vaccination have completed the primary dose of vaccination at least 3 months previously using 2 doses of CoronaVac. The age range corresponds to the active age of the health workers, so that was no respondent over 58 years. Most of the respondents are health workers who have direct contact with COVID-19 patients, so they have a high risk of exposure both in outpatient and inpatient services. The majority of respondents have never been diagnosed with COVID-19 through PCR based on New-all-record (NAR) data used by the Indonesian Ministry of Health (Karjoko et al., 2020).

Most of the health workers who took the third dose of vaccination had no previous history of illness because the initial screening for the implementation of primary dose vaccination in Indonesia is quite strict. Thus, health workers who have a history of severe asthma attacks, coagulopathy, malignancies, autoimmune diseases, and other serious diseases experience delays in completing the primary dose or have not received the primary dose at all. Previous medical history that had been documented included dyspepsia, bronchial asthma, and controlled hypertension with medication. Most of the respondents did not have regular medication for their illness. Most of the respondents (61.63\%) did not experience AEFI in the previous administration of CoronaVac vaccine doses 1 and 2. This is in line with this research that AEFI in the administration of inactivated virus vaccines tends to be mild or non-existent. The most common history of previous AEFIs was malaise, local pain, and fever. This is following the research of Chen, et al which stated that inactivated vaccines had a much lower incidence of AEFI than vaccines based on vector viruses or mRNA. Another study in Indonesia stated that $89.5 \%$ of respondents did not experience AEFI after Coronavac vaccination (Karjoko et al., 2021).

In this study, the incidence of AEFI after booster vaccination with mRNA-1273 was very high. Almost all respondents experienced AEFI, namely $99.7 \%$ was local AEFI and $93 \%$ was systemic AEFIs. AEFIs commonly occur with booster administration of all vaccines, but usually, it is a mild to a moderate level and did not cause serious symptoms. The immune response associated with vaccination causes reactions in the body such as increased blood flow and increased body temperature that varies from person to person (Karjoko et al., 2021) CDC data show that AEFI symptoms can include fatigue, headache, muscle aches, chills, fever, vomiting, and local reactions at the injection site. The high incidence of AEFI in the third dose of vaccination may be due to the formation of antibodies against the active ingredients of the vaccine obtained from the previous vaccination history. In addition, this booster vaccination was carried out on health workers, namely groups that have a risk of being exposed to COVID-19 before. Another study showed that the high incidence of AEFI was due to an immunological memory-induced reaction to the booster dose. In addition, the high incidence of AEFI may occur due to the higher booster dose than the recommendations of other immunization committees in the world. Indonesia used the full dose of Moderna booster $(0.5 \mathrm{ml}, 100 \mathrm{~g})$, while The Advisory Committee on Immunization Practices (ACIP) of the United States recommends a half primary dose $(0.25 \mathrm{ml}, 50 \mathrm{~g})$ of Moderna (mRNA-1273). Meanwhile, Pfizer/ BioNTech (BNT162b2) and Janssen used the same booster dose as the primary vaccination (Prasetyo et al., 2019).

Most of the AEFIs had an onset of 1-5 days after vaccination (74.03\%), with a duration of 24-48 hours (56.59\%). AEFI in Dose 3 was more common with a longer duration than the administration of vaccine doses 1 and 2. AEFIs could be reduced by the administration of NSAIDs (75.58\%). So far, there are limited studies that described the onset and duration of the booster dose of Moderna (mRNA-1273) in combination with CoronaVac. However, in general, mRNA-based vaccines have an AEFI incidence of 1-7 days of onset with a mild-moderate systemic AEFI, especially after the second dose. The high incidence of AEFIs cause only $68.22 \%$ of respondents to continue to work after the booster dose was given. None of the respondents required hospitalization or had serious AEFIs. This is in line with research from Moderna which recorded that most systemic AEFIs were mild-moderate and the complaints disappear by themselves in all cases (Widjaja et al., 2021).

Research from Apisarnthanarak explains that the high infection rate in health workers who have been vaccinated is caused by several factors. First, health workers are at very high risk for healthcare-associated SARS-CoV-2 transmission despite receiving 2 doses of the COVID-19 vaccine. This risk could be explained by 
the suboptimal immune response after CoronaVac, especially after day 60. Based on serological studies, healthcare workers who received CoronaVac tested after 60 days, had significantly lower antibody levels compared to those who received CoronaVac tested within 60 days after receiving CoronaVac. Similarly, the antibody levels of health workers who completed 2 doses of ChAdOx1 nCoV-19. This data indicates the need for a booster dose of the COVID-19 vaccine for health workers, especially for those receiving CoronaVac. Second, most health workers are categorized as having a high risk of exposure, especially when the usage of PPE is inadequate. Third, most health workers experience asymptomatic SARS-CoV-2 infection. Finally, the fact that all infected health workers only experience mild COVID-19 symptoms reduces the compliance of PPE usage (Palil et al., 2021)

In general, this study illustrates that the administration of the Moderna (mRNA-1273) booster after 2 doses of CoronaVac caused mild-moderate AEFI in almost all respondents but did not cause serious effects. Therefore, it is expected that this study could reduce the reluctance of other health workers who are still hesitant to carry out booster vaccinations. The AEFI number needs to be considered regarding the administration of the Moderna booster dose. Research is needed on the comparison of efficacy, safety, and AEFI in the use of homologous or heterologous booster vaccines using either full or half doses. The study results from the Immunization Commission of other countries can be considered in this determination. The study from Ai shows that vaccination with two doses of inactivated virus vaccine followed by a booster using a heterologous vaccine was considered safe and generated good immunogenic response in the adult population. The booster vaccine recalls and enhances the immune response against SARS-CoV-2 and its variants. This shows that the strategy of using heterologous vaccines as boosters can be considered to overcome new variants of COVID-19 (Putri et al., 2021).

\section{Conclusion}

Based on this study, most of the health workers experienced local and systemic AEFIs on the mRNA 1273 booster vaccination, but there was no reported serious AEFI. Local AEFIs were pain (95.35\%), swelling (37.6\%), and a red rash (11.24\%), while systemic AEFIs were myalgia (70.93\%), Febri (62.02\%), and malaise (38.37\%). In the third dose (mRNA 1273), the AEFI was similar with general recipients of mRNA vaccines but tends to be more frequent than the inactivated vaccine (CoronaVac). Evidence from other research suggests that booster doses of mRNA vaccines are given 6-8 months after the primary dose of vaccination. Many factors need to be considered in determining the schedule for giving booster doses to the population, include: immunogenicity, efficacy, and effectiveness of the primary vaccine; national pandemic situation; risk of infection with the new SARS-CoV-2 variant; as well as the logistics of available vaccines in a country. Several limitations to this study need to be acknowledged. First, the small size of the sample was not representative enough to draw general conclusions. Second, this study has not been able to analyze the specific factors that affect AEFI. Third, this study also cannot describe AEFIs with long-term onset as the data were only collected once. Further research is needed with a larger sample through serial interviews to describe in more detail the AEFI. In addition, further research on the effectiveness of booster doses for health workers and the community based on quantitative immunological aspects can be used as a basis in administrating booster vaccinations to protect those most at-risk, such as the elderly and immunocompromised populations.

Acknowledgments

We are grateful to two anonymous reviewers for their valuable comments on the earlier version of this paper.

Rakhmadhani, I., Yulida, E., Fauzan, A., \& Jaelani, A. K. (2022). Adverse events following immunization Post Moderna (mRNA-1273) booster vaccination after two primary doses of CoronaVac. International Journal of Health Sciences, 6(1), 160-173. https://doi.org/10.53730/ijhs.v6n1.3626 


\section{References}

Akbarov, A. N., \& Xabilov, D. N. U. (2021). The condition of the oral cavity in patients who have had a viral infection COVID-19. International Journal of Health \& Medical Sciences, 4(4), 381-383. https://doi.org/10.21744/ijhms.v4n4.1796

Arungpadang, M. P., Lusikooy, R. E., Kasim, F., Mappincara, M., \& Warsinggih, W. (2021). Correlation between levels of LGR-5 (leucine rich repeat containing protein coupled receptor 5) with clinical aspects and colorectal carcinoma stage. International Journal of Health Sciences, 5(3), 331-343. https://doi.org/10.53730/ijhs.v5n3.1541

Asman, A., Asman, A., \& Dewi, A. K. (2021). Community nursing strategies for tourism health families during COVID-19 pandemic. International Journal of Health Sciences, 5(3), 224-231. https://doi.org/10.53730/ijhs.v5n3.1449

Bocheliuk, V. Y., Spytska, L. V., Mamicheva, O. V., Panov, M. S., \& Kordonets, V. V. (2021). Psychological Features of Post-COVID Syndrome Course. International Journal of Health Sciences, 276-285. https://doi.org/10.53730/ijhs.v5n3.1503

Candra, I. W., Sumirta, I. N., \& Mustika, I. W. (2021). Effect of self-hypnosis therapy with positive self-talk on stress levels of COVID-19 mutual cooperation task force. International Journal of Health Sciences, 5(3), 441448. https://doi.org/10.53730/ijhs.v5n3.1802

Cuenca, R. O. S. A., Blanchard, T. G., Czinn, S. J., Nedrud, J. G., Monath, T. P., Lee, C. K., \& Redline, R. W. (1996). Therapeutic immunization against Helicobacter mustelae in naturally infected ferrets. Gastroenterology, 110(6), 1770-1775. https://doi.org/10.1053/gast.1996.v110.pm8964402

Erickson, L. J., De Wals, P., \& Farand, L. (2005). An analytical framework for immunization programs in Canada. Vaccine, 23(19), 2470-2476. https://doi.org/10.1016/j.vaccine.2004.10.029

Handayani, I. G. A. K. R., Karjoko, L., \& Jaelani, A. K. (2019). Model Pelaksanaan Putusan Mahkamah Konstitusi yang Eksekutabilitas Dalam Pengujian Peraturan Perundang-Undangan di Indonesia. BESTUUR, 7(1), 3646.

Heininger, U. (2004). The success of immunization-shovelling its own grave?. Vaccine, 22(15-16), 20712072. https://doi.org/10.1016/j.vaccine.2004.01.018

Iurii, M., Volodymyr, Y., Vasyl, S., Oleksandr, B., \& Oleh, S. (2021). Optimal management of early surgery of chronic pancreatitis. International Journal of Health Sciences, 5(3), 373-385. https://doi.org/10.53730/ijhs.v5n3.1638

Jaelani, A. K., Handayani, I. G. A. K. R., \& Karjoko, L. (2020). Development of tourism based on geographic indication towards to welfare state. International Journal of Advanced Science and Technology,29(3s), 1227-1234.

Kaml, M., Weiskirchner, I., Keller, M., Luft, T., Hoster, E., Hasford, J., ... \& Grubeck-Loebenstein, B. (2006). Booster vaccination in the elderly: their success depends on the vaccine type applied earlier in life as well as on pre-vaccination antibody titers. Vaccine, 24(47-48), 6808-6811. https://doi.org/10.1016/j.vaccine.2006.06.037

Karjoko, L., Gunawan, S., Sudarwanto, A. L. S., Heriyanti, Rosidah, Z. N., Handayani, I. G. A. K., ... Hanum, W. N. (2020). Patent Policy On The Pharmaceutical Sector In Indonesia, 23(5), 1-13.

Karjoko, L., Handayani, I. G. A. K. R., Jaelani, A. K., Barkhuizen, J., \& Hayat, M. J. (2021). The Urgency of Restorative Justice on Medical Dispute Resolution in Indonesia. AL-IHKAM: Jurnal Hukum \& Pranata Sosial, 16(2), 362-392.

Karjoko, L., Handayani, I. G. A. K. R., Sudarwanto, A. S., Winarno, D. W., Jaelani, A. K., \& Hanum, W. N. (2021). The Consequence of The Decision of The Constitutional Court In Forestry On The Recognition Of Traditional Forests In Indonesia. Journal of Legal, Ethical and Regulatory Issues, 24(5), 1-8.

Karjoko, L., Jaelani, A. K., Tegnan, H., Glaser, H., \& Hayat, M. J. (2021). Islamic Court's Approach to Land Dispute in Inheritance Cases. AHKAM: Jurnal Ilmu Syariah, 21(2).

Karjoko, L., Rosidah, Z. N., \& Handayani, I. G. A. K. R. (2019). Refleksi Paradigma Ilmu Pengetahuan Bagi Pembangunan Hukum Pengadaan Tanah. Bestuur, 7(1), 1-14.

Kim, S. W., \& Su, K. P. (2020). Using psychoneuroimmunity against COVID-19. Brain, behavior, and immunity, 87, 4-5. https://doi.org/10.1016/j.bbi.2020.03.025 
Kong, J., Cuevas-Castillo, F., Nassar, M., Lei, C. M., Idrees, Z., Fix, W. C., ... \& Mathew, A. (2021). Bullous drug eruption after second dose of mRNA-1273 (Moderna) COVID-19 vaccine: Case report. Journal of Infection and Public Health, 14(10), 1392-1394. https://doi.org/10.1016/j.jiph.2021.06.021

Lintang, L. C., Martufi, A., \& Ouwerker, J. W. (2020). The Alternative Concepts of Blasphemy Law in Indonesia: Legal Comparison with Ireland and Canada. Bestuur, 9(1), 13-25.

Lytvyn, V., Akimova, O., Kuznetsova, H., Zenchenko, T., Stepanenko, O., \& Koreneva, I. (2021). The use of synchronous and asynchronous teaching methods in pedagogical education in COVID-19 terms. International Journal of Health Sciences, 5(3), 617-629. https://doi.org/10.53730/ijhs.v5n3.2681

Manullang, S. O. (2021). Giving COVID-19 vaccines to citizens: Understanding legal basis. International Journal of Health Sciences, 5(3), 364-372. https://doi.org/10.53730/ijhs.v5n3.1598

Mariya, M., Kuzyk, P., \& Diegtiar, O. (2021). Promoting healthy births and reducing infant mortality through national health system. International Journal of Health Sciences, 5(3), 449-460. https://doi.org/10.53730/ijhs.v5n3.1905

Martyniv, L., Sokolova, A., Kurinna, S., Kopeliuk, O., Sediuk, I., \& Khomova, O. (2021). The modern problems and prospects of music formation and art education development during COVID-19. International Journal of Health Sciences, 5(3), 670-680. https://doi.org/10.53730/ijhs.v5n3.2936

McMahon, D. E., Amerson, E., Rosenbach, M., Lipoff, J. B., Moustafa, D., Tyagi, A., ... \& Freeman, E. E. (2021). Cutaneous reactions reported after Moderna and Pfizer COVID-19 vaccination: A registry-based study of 414 cases. Journal of the American Academy of Dermatology,85(1), 46-55. https://doi.org/10.1016/j.jaad.2021.03.092

Mishra, U. K., \& Negi, A. (2021). Transgender and the Right to Employment in India: Analysing the Trajectories of Discrimination. Bestuur, 9(1), 26-33.

Nataliia, V., Barzylovych, A., Zabolotna, A., Boiko, M., \& Rybchych, I. (2021). Healthcare facilities management in digitalization context. International Journal of Health Sciences, 5(3), 429-440. https://doi.org/10.53730/ijhs.v5n3.1773

Noor, H. J., Afkar, K., \& Glaser, H. (2021). Application of Sanctions Against State Administrative Officials Failing to Implement Administrative Court Decisions. Bestuur, 9(1), 53-67.

Palil, M. R., Ismail, I. S., Zain, N. H. M., \& Bakar, A. A. A. (2021). Social Enterprise and Taxation Policy: A Systematic Literature Review. BESTUUR, 9(2), 135-143.

Patamatamkul, S., Buranrat, B., \& Thammawat, S. (2021). Induction of robust neutralizing antibodies against the COVID-19 Delta variant with ChAdOx1 nCoV-19 or BNT162b2 as a booster following a primary vaccination series with CoronaVac. medRxiv.

Prasetyo, B., Handayani, I. G. A. K. R., Sulistyono, A., \& Karjoko, L. (2019). Legal framework for social security state civil apparatus. International Journal of Advanced Science and Technology, 28(20), 310-313.

Putri, W. B., Widyasari, V., Musabula, J., \& Hayat, M. J. (2021). Medicolegal Perspective on Physician-Induced Demand Issue. Bestuur, 9(1), 77-89.

Rahkmonova, S., Khaytboyev, J., Zargarova, N., Otajonova, D., \& Kazakov, K. (2021). Kidney complications after COVID-19. International Journal of Health Sciences, 5(3), 393-402. https://doi.org/10.53730/ijhs.v5n3.1698

Schwarz, T. F., Horacek, T., Knuf, M., Damman, H. G., Roman, F., Dramé, M., ... \& Jilg, W. (2009). Single dose vaccination with AS03-adjuvanted H5N1 vaccines in a randomized trial induces strong and broad immune responsiveness to booster vaccination in adults. Vaccine, 27(45), 6284-6290. https://doi.org/10.1016/j.vaccine.2009.01.040

Shamshurina, N. G., Shamshurin, V. I., Laamarti, Y. A., Ryabchikova, L. N., Nikolaev, A. A., \& Peremibeda, P. A. (2021). Public administration strategy of healthcare system for seniors. International Journal of Health Sciences, 5(3), 630-638. https://doi.org/10.53730/ijhs.v5n3.2720

Sudarwanto, A. S., Karjoko, L., Handayani, I. G. A. K. R., \& Jaelani, A. K. (2021). POSITION OF FREEDOM OF CONTRACT PRINCIPLE IN FORESTRY PARTNERSHIP POLICY. Journal of Legal, Ethical and Regulatory Issues, 24(5), 1-11.

Suiraoka, I. P., Nursanyoto, H., \& Suastiti, N. M. A. (2021). Determinant of child obesity in COVID-19 pandemic and analysis of intervention requirement. International Journal of Health Sciences, 5(3), 503-512. https://doi.org/10.53730/ijhs.v5n3.2116

Sukismanto, S., Hartono, H., Sumardiyono, S., \& Andayani, T. R. (2021). Social support role of occupational

Rakhmadhani, I., Yulida, E., Fauzan, A., \& Jaelani, A. K. (2022). Adverse events following immunization Post Moderna (mRNA-1273) booster vaccination after two primary doses of CoronaVac. International Journal of Health Sciences, 6(1), 160-173. https://doi.org/10.53730/ijhs.v6n1.3626 
safety and health implementation in informal sector during COVID-19 pandemic. International Journal of Health Sciences, 5(3), 416-428. https://doi.org/10.53730/ijhs.v5n3.1746

Suryasa, I. W., Rodríguez-Gámez, M., \& Koldoris, T. (2021). Get vaccinated when it is your turn and follow the local guidelines. International Journal of Health Sciences, 5(3), $\mathrm{x}$-xv. https://doi.org/10.53730/ijhs.v5n3.2938

Tetro, J. A. (2020). Is COVID-19 receiving ADE from other coronaviruses?. Microbes and infection, 22(2), 72-73. https://doi.org/10.1016/j.micinf.2020.02.006

Urinov, M., Alikulova, N., Zukhritdinova, D., Usmonov, M., \& Urinov, R. (2021). Clinical, laboratory and instrumental indicators in patients who have undergone COVID-19. International Journal of Health Sciences, 5(3), 403-415. https://doi.org/10.53730/ijhs.v5n3.1719

Vokhidov, U. N., Shernazarov, O. N., Yakubdjanov, D. D., Djuraev, J. A., \& Sharipov, S. S. (2021). Paralytic stenosis of the larynx: Patients surgical overview. International Journal of Health Sciences, 5(3), 386-392. https://doi.org/10.53730/ijhs.v5n3.1680

Wahyuni, S., Chalid, S. M. T., Pelupessy, N. U., Arifuddin, S., Idris, I., \& Usman, A. N. (2022). Comparison of the use of shock index and modified early obstetric warning score in COVID-19 obstetric emergency patients as ICU care parameters. International Journal of Health \& Medical Sciences, 5(1), 80-90. https://doi.org/10.21744/ijhms.v5n1.1844

Widana, I.K., Sumetri, N.W., Sutapa, I.K., Suryasa, W. (2021). Anthropometric measures for better cardiovascular and musculoskeletal health. Computer Applications in Engineering Education, 29(3), 550561. https://doi.org/10.1002/cae.22202

Widjaja, G., Zahari MS, M., Hastuti, P., Nugraha, A. R., \& Kusumawaty, I. (2021). Understanding COVID-19 vaccination program among Indonesian public: A challenge and hope for government. International Journal of Health Sciences, 5(3), 212-223. https://doi.org/10.53730/ijhs.v5n3.1429

Wijaya, M. P. H., \& Ali, M. Z. (2021). Legislation Impediments in Reorganising Government Bodies in Indonesia. BESTUUR, 9(1), 1-12.

Yussoff, S. F. B. C., \& Nordin, R. (2021). Freedom of Expression in Malaysia: Compatibility with the International Human Rights Standard. Bestuur, 9(1), 34-42.

Zepp, F., Heininger, U., Mertsola, J., Bernatowska, E., Guiso, N., Roord, J., ... \& Van Damme, P. (2011). Rationale for pertussis booster vaccination throughout life in Europe. The Lancet infectious diseases, 11(7), 557-570. https://doi.org/10.1016/S1473-3099(11)70007-X

Zulfa, S. Z., Emilia, O., \& Hidayat, A. (2021). Midwives preparation to provide delivery services in independent midwife practice during COVID-19 pandemic. International Journal of Health Sciences, 5(3), 344-351. https://doi.org/10.53730/ijhs.v5n3.1554 


\section{Biography of Authors}

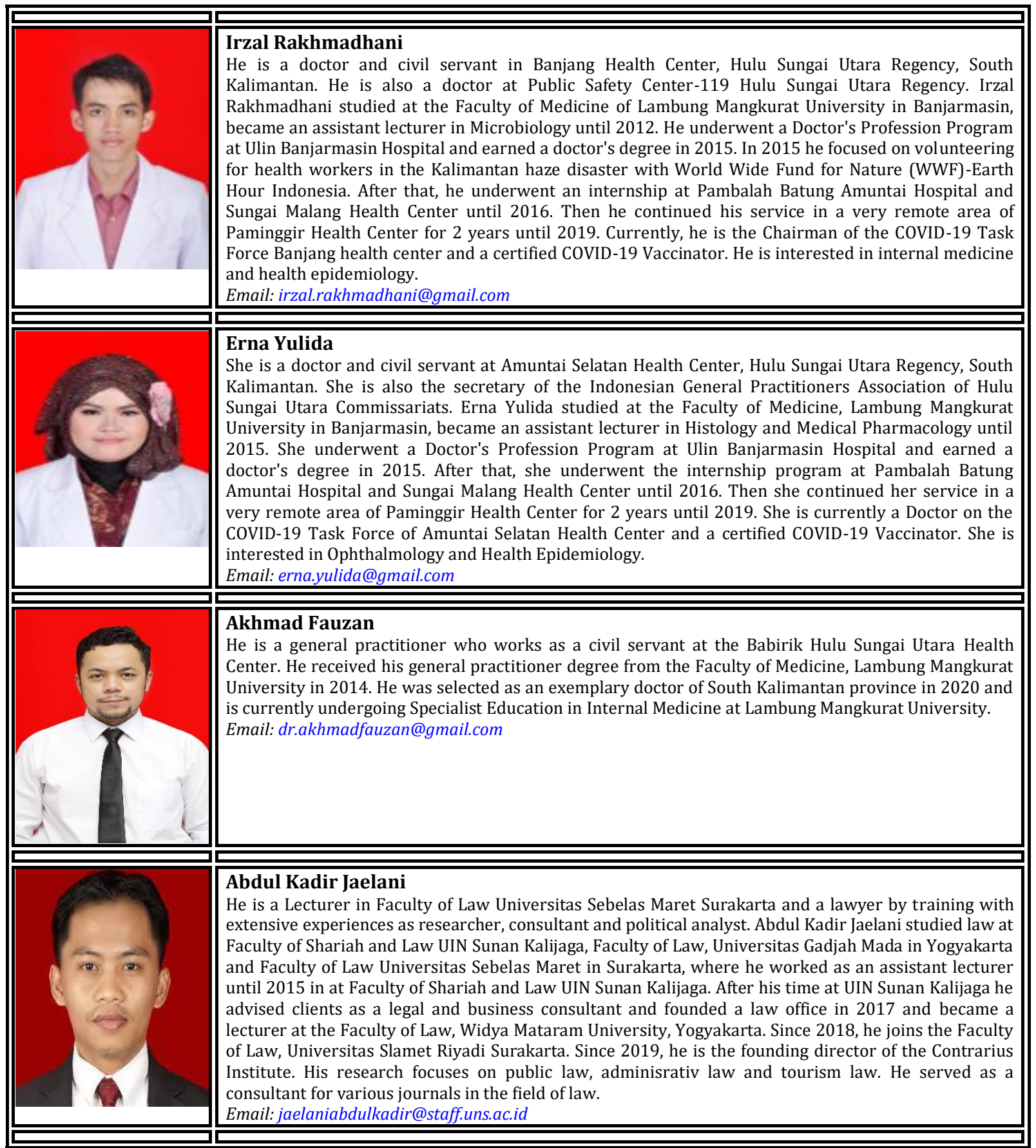

Rakhmadhani, I., Yulida, E., Fauzan, A., \& Jaelani, A. K. (2022). Adverse events following immunization Post Moderna (mRNA-1273) booster vaccination after two primary doses of CoronaVac. International Journal of Health Sciences, 6(1), 160-173. https://doi.org/10.53730/ijhs.v6n1.3626 